\title{
Parliamentary elections in Bulgaria 2013: How durable are the tendencies of authoritarian populism in a fragile democracy?
}

\begin{abstract}
This article reviews the outcome of the 2013 general election in Bulgaria, which was held against the backdrop of mass protests in January which had brought a premature end to the previous government. The election proved to be highly unusual and has resulted in a finely-balanced political situation which, the author argues, cannot be understood without reference to Bulgaria under the previous populist government. A review of this situation sets the starting point for the article, which analyses the implications of the result for the four parties which make up the new legislature, as well as for others on the political scene. There were indeed a number of 'mini-surprises' in the result, with the most important outcomes being: the end of the 'traditional right' in party political terms; the failure of certain parties to make much of an impact, including those identified with the protests; and the continued growth in the vote for nationalist parties. The author concludes that the next period is key for the continued development of Bulgaria's fragile democracy into a consolidated one.
\end{abstract}

Keywords: street protests, austerity measures, poverty, social exclusion, inequality, democratic development, populist authoritarianism, corruption, media freedom, political legitimacy, political participation, fragmentation, nationalism

Introduction

The parliamentary election in Bulgaria in May 2013 again gave rise to media headlines. They were far from the highest levels of political exotics, such as the landslide victory of the hastily-formed and even unregistered party of former king Simeon SaxeCoburg-Gotha in 2001, who then became the prime minister; or the coming to power of his former bodyguard, the populist Boyko Borisov, with his Citizens for the European Development of Bulgaria (GERB) party in 2009. Nevertheless, the elections in 2013 laid bare a series of paradoxes which are unprecedented in the context of Bulgarian political life.

Firstly, the election campaign itself was unusual. For the first time since 1997, the elections were pre-term ones due to the cabinet's resignation caused by the mass protests against poverty, high prices and social injustice. It was expected that the campaign would focus precisely on these issues, but it turned into a debate about illegal eavesdropping and electoral manipulation. Even the day of reflection, instead of the legally-required silence, generated unexpected political noise alongside the discovery of 350000 illegally-printed ballot papers in a printing house owned by a GERB official. 
Secondly, the GERB government might have been overthrown by massive civil protest, but the party won the highest number of votes. This was the first time since the beginning of the transition that a former ruling party has succeeded in gaining the greatest number of votes and mandates. Yet, GERB leaders did not enjoy a victory; they did not even show up at the traditional post-election press conference.

Thirdly, after remaining hidden from the public for a few days, GERB leaders surprisingly announced that they would seek the annulment of the election results. This was the first time that the governing party, which controlled the whole election process and which received the best result, has wanted the results voided on the grounds of a legal violation.

Fourthly, for the first time after general elections, the formation of a coalition with its own majority has not been possible: the governing coalition has only half of the mandates and must rely on help from 'outside'. This means that otherwise incompatible and hostile parties have to act in the same direction.

Taking into account all these peculiarities, the prominent Bulgarian sociologist, Petar-Emil Mitev, concludes, however, that these unusual, even absurd, phenomena have their logical explanation and that it lies in the past four years. ${ }^{1}$ Indeed, the election results and their consequences cannot be understood unless we return to the basic features of the political, social and economic situation in Bulgaria during the government of GERB and its Prime Minister, Boyko Borisov.

\section{What happened during the 'Borisov Era' in Bulgaria: Social and economic background}

At the beginning of the Borisov government in 2009, expectations and trust among Bulgarian citizens were high, but the end was marked by mass demonstrations, police violence and suicides by immolation. The week-long street protests erupted in late January 2013 and spread quickly. Hundreds of thousands demonstrated in more than thirty cities. The occasion was the extremely high electricity and heating bills, which were unaffordable for many people. However, behind this particular occasion were deeper reasons - rising poverty, social injustice and acute social polarisation, as well as growing corruption and the inability of politicians to resolve the basic problems of the people.

This unacceptable situation is assuredly not only the fault of GERB. However, the drastic austerity measures of the GERB government, which has kept the public finances healthy, has inflicted heavy damage on the economy. Bulgaria has curbed its public deficit and was one of the few EU countries to stick to the deficit rule of three per cent of GDP. The country is an example of the rule that an emphasis only on financial stability destroys social stability - and thus, the economy as a whole: a recent study by the Bulgarian Industrial Association shows that investment in the country has declined by $79 \%$ in the last five years, and that $46 \%$ of enterprises have virtually stopped working.

1 Petar-Emil Mitev (2013) Paper presented at the Friedrich Ebert Foundation forum Bulgaria after the election Sofia, 22 May, p. 1. 
The austerity measures and inadequate economic and social policies have exacerbated the problems of citizens with living standards and have led to growing poverty and inequality.

In the EU Employment and Social Situation Quarterly Review (March 2013), ${ }^{2}$ the European Commission presents a separate analysis of the social situation in Bulgaria. The following excerpts from this analysis show the picture at the end of Borisov's government:

- the intense economic austerity measures in Bulgaria during the recession led to a marked improvement in the budget position (the deficit was cut from almost $4 \%$ of GDP in 2010 to $1 \%$ in 2012) but at the cost of increasing social unrest

- local analysts estimate that $85 \%$ of household monthly incomes are spent on basic necessities. Almost one-half of the Bulgarian people (44\%) experienced severe material deprivation in 2011, the highest percentage in the EU and five times higher than the EU average

- the other social indicators also highlight that Bulgaria was the poorest member state in 2011: $49 \%$ of the total population, and 52\% of children, were at risk of poverty or social exclusion, compared to $24 \%$ and $27 \%$ on average across the EU-15. The situation is even worse for pensioners aged over 65 , some $61 \%$ of whom are at risk of poverty or social exclusion

- the average salary in Bulgaria is the lowest among the member states, at 768 leva (€393) for September 2012. Twenty-two per cent of the labour force are employed on the minimum wage, amounting to 310 leva (€159) which is the second lowest in the EU-17

- despite modest GDP growth, the labour market has remained weak, with employment down by over $4 \%$ in 2011 and almost $2 \%$ in 2012. Unemployment climbed from $5.6 \%$ in 2008 to over $12 \%$ in 2012 , with youth unemployment more than doubling over the same period to reach $28 \%$ (in the meantime, the unemployment rate reached $13.8 \%$ in the first quarter of 2013).

If we look at trends during the last four-five years, the data for 2008-2012 show that poverty has increased significantly. Thus, in the previous period, i.e. between 2006 and 2008, there was a reduction in the share of people living in material deprivation, from $57.7 \%$ in 2006 to $41.2 \%$ in 2008 . The trend between 2008 and 2012 was exactly the opposite, reaching its peak in 2010 of $45.7 \% .^{3}$

In the last few years, the trend of a relative reduction of the risk of poverty and social exclusion, which had been observed in the period between 2003 and 2008, has been reversed in Bulgaria and we are now witnessing a new wave of an increased risk of poverty and social exclusion. Thus, in the period between 2008 and 2011, the per-

2 EU Employment and Social Situation Quarterly Review - March 2013 (26 March 2013) http:// ec.europa.eu/social $/$ main.jsp?catId=738\&langId=en\&pubId=7482.

3 Eurostat 2013, EU Policy indicators, Europe 2020 indicators: Severely materially deprived people available at:

http://epp.eurostat.ec.europa.eu/tgm/table.do?tab=table\&init=1\&plugin=0\&language $=$ en\&pcode $=\mathrm{t} 2020 \quad 53$. 
centage of Bulgaria's population living at risk of poverty and social exclusion grew steadily, from $44.8 \%$ in 2008 to $46.2 \%$ in $2009,49.2 \%$ in 2010 and $49.1 \%$ in $2011 .^{4}$

The same trend can be seen from another viewpoint: the share of the population living in families with very low levels of labour activity. In 2008, people living in such families in Bulgaria totalled $8.1 \%$ of the population, or 470000 , whereas - albeit with some fluctuations in 2009 and 2010 (respectively $6.9 \%$ in 2009 and $7.9 \%$ in 2010) they are now $11 \%$ for 2011 , or 623000 people. $^{5}$

At the same time, various data show a trend of a steady growth in inequality in the income distribution. For the period 2003-2011, the Gini index for the country increased from 24 to 35.1, defining Bulgaria as the country with the most significant inequality in income distribution in the EU-27. The trend is the same when using the indicator of the income of the $20 \%$ highest income earners compared to the other $80 \%$; in 2011 , this reached 6.5 and is again among the highest in the EU-27. ${ }^{6}$

\section{Regression of Bulgarian democracy}

Borisov likes to praise himself as the 'The most democratic prime minister that Bulgaria has ever had and will ever have', but what is perhaps more serious has been the damage that GERB and its leader have caused to the vulnerable Bulgarian democracy.

It is not by chance that, in addition to the social problems, the protesters were demanding a new political system that allows real accountability of the institutions and greater opportunities for control by the citizens. Another feature was also unrest with the authoritarian style of politics introduced by Borisov and his paternalistic behaviour towards citizens, although this was less visible.

In its first appearance in parliamentary elections, GERB won the most votes and mandates in 2009. ${ }^{7}$ It had no outright majority in the National Assembly (taking 117 out of the 240 seats in Parliament) but it did not hesitate to assume sole power, having received the support of the nationalist Ataka and the traditional right in the guise of the Blue Coalition.

The victory of GERB was due exclusively to the charisma of its leader, Boyko Borisov, who successfully took on the role as 'saviour of the nation', promising to combat poverty, corruption and injustice. Becoming Prime Minister with enormous

4 Eurostat 2013, EU Policy indicators, Europe 2020 indicators: People at risk of poverty or social exclusion available at:

http://epp.eurostat.ec.europa.eu/tgm/table.do?tab=table\&init=1\&plugin=0\&language $=$ en\&pcode $=\mathrm{t} 2020 \quad 50 \&$ tableSelection $=2$.

5 Eurostat, 2013, EU Policy indicators, Europe 2020 indicators: Headline indicators available at: http://epp.eurostat.ec.europa.eu/portal/page/portal/europe_2020_indicators/headline_indicators.

6 Eurostat (2013) Statistics by theme/Population and social conditions/Income, Social inclusion and living conditions/Database/Income distribution and monetary poverty/Distribution of income. Table: S80/S20 Income quintile share ratio by sex and selected age group (source: SILC) (ilc_di11), http://appsso.eurostat.ec.europa.eu/nui/show.do?dataset=ilc_di11\&lang=en.

7 Dobrin Kanev (2010) 'Political Change in Bulgaria: interpreting the 2009 General Election results' in SEER Journal for Labour and Social Affairs in Eastern Europe 13(1): 41-54. 
power in his hands, he managed to bring the concentration and personalisation of power to a level unprecedented in the years after 1989.

The GERB party was itself established as a typical 'leader's party', following a more or less authoritarian model. The statute of the party allows for the leader to avoid, by all means, each kind of top-down control and the democratic formation of political will. It provides for the following organisational structure: a leader; a political committee of twelve people, led by the leader; and a congress which, however, convenes only every three years. The lack of a middle level of party leadership in practice makes the party purely an instrument of its leader.

From this perspective, it is no wonder that, after coming to power, GERB and Borisov tried to apply this populist-authoritarian model to the Bulgarian political system as a whole. The result over the past four years has been that there have been tendencies towards a corruption of the entire political process.

First of all, Parliament was turned into a kind of 'rubber stamp' institution using the majority as a mirror of the will of the prime minister. Bulgarian 'party democracy' allows the PM and the cabinet to become extremely powerful in the case of a homogeneous parliamentary majority. In the last years, the legislative body has, to a great extent, lost its own identity, falling back into the role of an institution carrying out all the wishes of the government in power.

As far as Parliament was strongly dominated by the majority and, at the end of the day, by the government and the prime minister, opportunities for the opposition to influence politics were restricted and, in the GERB-dominated legislature, the opposition was driven into the corner of parliamentary life.

The attitude of Borisov towards Parliament and MPs was arrogant and he treated them as of negligible interest. Backed by the majority, he avoided the parliamentary control even of issues which were of great importance to the country. His stance has been usually that it is the 'expression of his goodwill' that Parliament was informed at all. ${ }^{8}$ For example, after the meeting of the European Council in December 2011, four parliamentary groups (all those except GERB) repeatedly insisted on holding a hearing of the PM on the results of the meeting. However, the majority, through its vote, rejected all the requests. Finally, the PM sent the foreign minister, who had not himself attended the meeting, to inform MPs. ${ }^{9}$ The conclusion of Ivan Kostov, the former PM (1997-2001) and co-chair of the Blue Coalition, sharply underlined this approach of the PM to ignore Parliament:

The Bulgarian PM for some reason does not wish to come here and tell us what exactly has been negotiated and which are the positions that he intends to present in negotiations on the Financial Stability Pact. ${ }^{10}$

8 Minutes of plenary proceedings Bulgarian National Assembly, 1 April 2011 http://www.parliament.bg/bg/plenaryst/ID/2587 [last accessed on 19 July 2012].

9 Minutes of plenary proceedings Bulgarian National Assembly, 14 December $2011 \mathrm{http}: / /$ www.parliament.bg/bg/plenaryst/ID/2680 [last accessed on 19 July 2012].

10 Minutes of plenary proceedings Bulgarian National Assembly, 15 December $2011 \mathrm{http}: / /$ www.parliament.bg/bg/plenaryst/ID/2681 [last accessed on 19 July 2012]. 
Furthermore, as a parliamentary party without an outright majority, GERB secured its domination by destroying other parliamentary factions and by drawing out MPs from them, through dubious means, to support the government. Typical was the case of Ataka, whose parliamentary group was halved since eleven of its 21 MPs declared themselves 'independent', almost all subsequently announcing their support for GERB. Behind these scenes, there was also a financial stimulus since the party law allows 'independents' to transfer some of the state subsidy from the party on whose lists they entered Parliament to the party they prefer. The situation was repeated, albeit on a smaller scale, with members of the Movement for Rights and Freedoms (DPS) grouping. Two of them left the group, supported GERB, and, ultimately, founded a new party with the support of GERB and the Turkish government.

The formation of new 'sister parties' was another aspect of this manipulation of the political process. For example, the new People's Freedom and Dignity Party had the aim of competing with DPS among their traditional voters in Bulgaria and in Turkey and, at the end of the day, of serving as a sort of 'parliamentary crutch' for GERB in the next legislature.

Such a role has also been designed for some of the existing parties like Order, Law and Justice (RZS) and the Union of Democratic Forces (SDS), whose leadership was inclined to be dependent on GERB.

Part of the explanation of the inability of GERB to build a coalition after the 2009 election can be found in this strategy that failed in the run-up to the election. Additionally, part of the explanation of the unusual election campaign in 2013 is the conviction of most political parties that GERB had manipulated the local and presidential elections in 2011 and would try to manipulate the general election process.

This is the reason that, for the first time since 1997, instead of the usual twenty, there were more than two hundred international observers present. We should also mention here the unprecedented decision of five otherwise mutually hostile parties, from across the political spectrum, to invite the Austrian SORA Institute to conduct a parallel counting of the votes.

The danger to the integrity of the election has also been seen in that the campaign manager of GERB is, invariably, the Interior Minister Tsvetan Tsvetanov, who is suspected of having used pressure on voters. The report of the OSCE observers states that:

Several political parties questioned the role and involvement of the Ministry of the Interior in political life and the electoral process. ${ }^{11}$

After a series of scandals during the last four years connected with Tsvetanov, involving the disproportionate use of police force and widespread, or unregulated, use of special surveillance, it was again him who stood at the centre of a scandal during the campaign with the Sofia prosecutor holding him directly responsible for the illegal

11 OSCE Report on Bulgaria's Early Elections Mentions Wiretapping Scandal 4 May 2013, available at: http://www.novinite.com/search news.php?do search=no\&thequery=OSCE + Report + on + Bulgaria $\% 27 \mathrm{~s}+$ Early+Elections + Mentions + Wiretapping + Scandal\&area $=\& \mathrm{x}=7 \& \mathrm{y}=11$. 
wiretapping of politicians. The scandal even reached the European Parliament. Guy Verhofstadt, the chair of the liberal ALDE group, stated that the sanctioning of the illegal wiretapping of opposition politicians in Bulgaria by the state authorities undermined democracy and the fairness of the electoral process, while the Socialist \& Democrat Group called on Tsvetanov to step down from the position of GERB campaign leader. $^{12}$

The fears of electoral manipulation were strengthened as a result of the seizure, as mentioned in the Introduction, of 350000 illegal ballot papers (it later turned out that the number was 480 000) from a printing house owned by a GERB councillor.

Looking at all this in the round, it is not surprising that all agencies and researchers involved with measuring the state and quality of political regimes have identified a regressive trend in Bulgarian democracy.

According to the Economist Intelligence Unit, Bulgaria's index of democratisation worsened between 2006 and 2012, and the country dropped from 49th to 54th place, remaining a 'flawed democracy'. ${ }^{13}$

Freedom House's Nations in Transit survey classified Bulgaria as a consolidated democracy between 2006 and 2008 but, since 2009, it has moved to being a semiconsolidated democracy, with a deteriorating assessment throughout the period until $2012 .{ }^{14}$

12 EU Liberals: Wiretapping in Bulgaria Imperils Democracy 17 April 2013, available at: http:// www.novinite.com/view news.php?id=149638.

13 Economist Intelligence Unit Democracy Index available at: http://www.eiu.com/default.aspx (home page).

14 Freedom House Nations in Transit available at: http://www.freedomhouse.org/report/nations-transit/2012/bulgaria. 
Table 1 - State of Bulgarian democracy, 2006-2012

\begin{tabular}{|l|l|c|c|c|c|c|c|}
\hline \multicolumn{2}{|c|}{} & $\mathbf{2 0 0 6}$ & $\mathbf{2 0 0 8}$ & $\mathbf{2 0 0 9}$ & $\mathbf{2 0 1 0}$ & $\mathbf{2 0 1 1}$ & $\mathbf{2 0 1 2}$ \\
\hline $\begin{array}{l}\text { Economist } \\
\text { Intelligence } \\
\text { Unit }\end{array}$ & $\begin{array}{l}\text { Democrati- } \\
\text { sation index }\end{array}$ & 7.10 & 7.02 & & 6.84 & 6.78 & 6.72 \\
\cline { 2 - 8 } & Place & 49 & 52 & & 51 & 52 & 54 \\
\cline { 2 - 8 } & $\begin{array}{l}\text { Democracy } \\
\text { status }\end{array}$ & Flawed & Flawed & & Flawed & Flawed & Flawed \\
\hline $\begin{array}{l}\text { Freedom } \\
\text { House - } \\
\text { Nations in } \\
\text { Transit }\end{array}$ & $\begin{array}{l}\text { Democracy } \\
\text { Score }\end{array}$ & 2.93 & 2.86 & 3.04 & 3.04 & 3.07 & 3.14 \\
\cline { 2 - 8 } & $\begin{array}{l}\text { Democracy } \\
\text { status }\end{array}$ & $\begin{array}{c}\text { Consol- } \\
\text { idated }\end{array}$ & $\begin{array}{c}\text { Consol- } \\
\text { idated }\end{array}$ & $\begin{array}{c}\text { Semi } \\
\text { consol- } \\
\text { idated }\end{array}$ & $\begin{array}{c}\text { Semi } \\
\text { consol- } \\
\text { idated }\end{array}$ & $\begin{array}{c}\text { Semi } \\
\text { consol- } \\
\text { idated }\end{array}$ & $\begin{array}{c}\text { Semi } \\
\text { consol- } \\
\text { idated }\end{array}$ \\
\hline $\begin{array}{l}\text { Bertelsmann } \\
\text { Foundation }\end{array}$ & Index & 7.98 & 8.44 & & 8.36 & & 8.24 \\
\cline { 2 - 8 } & $\begin{array}{l}\text { Political } \\
\text { Transforma- } \\
\text { tion }\end{array}$ & 8.45 & 8.70 & & 8.75 & & 8.65 \\
\hline
\end{tabular}

Source: Compiled by author using data from: Economist Intelligence Unit Democracy Index http:// www.eiu.com/defaultaspx (home page); Freedom House Nations in Transit http://www.freedomhouse.org/report/nations-transit/2012/bulgaria; Bertelsmann Foundation, BTI 2012, Bulgaria Country Report http://www.bti-project.de/laendergutachten/ecse/bgr.

Table 2 - Bulgarian democracy compared to the new democracies in central and eastern Europe

\begin{tabular}{|l|c|c|c|c|}
\hline & $\mathbf{2 0 0 6}$ & $\mathbf{2 0 0 8}$ & $\mathbf{2 0 0 9}$ & $\mathbf{2 0 1 2}$ \\
\hline Slovenia & 1.75 & 1.86 & 1.93 & 1.89 \\
\hline Estonia & 1.96 & 1.93 & 1.93 & 1.93 \\
\hline Latvia & & 2.07 & 2.18 & 2.11 \\
\hline Czech Republic & 2.25 & 2.14 & 2.18 & 2.18 \\
\hline Poland & & 2.39 & 2.25 & 2.14 \\
\hline Hungary & 2.00 & 2.14 & 2.29 & 2.86 \\
\hline Lithuania & & 2.25 & 2.29 & 2.29 \\
\hline Slovakia & & 1.96 & 2.46 & 2.50 \\
\hline Bulgaria & 2.93 & 2.86 & 3.04 & 3.14 \\
\hline Romania & 3.39 & 3.36 & 3.36 & 3.43 \\
\hline
\end{tabular}

Source: Compiled by author using data from: Freedom House Nations in Transit http://www.freedomhouse.org/report-types/nations-transit. 
If we take a more precise look at the different dimensions of the democratic process, it is corruption and the state of the media that has aggravated the state of Bulgarian democracy.

Corruption has been, and still remains, an important issue as well as a serious concern for Bulgaria. GERB and Borisov promised in 2009 to put an end to corruption and many Bulgarians believed them. It did not happen; on the contrary, corruption levels are growing higher. Bulgaria was ranked $75^{\text {th }}$ out of 176 countries surveyed in Transparency International's 2012 Corruption Perceptions Index and 86 th in 2011, compared with $71^{\text {st }}$ place in $2009 .{ }^{15}$ And Eurobarometer surveys show that sixty eight per cent of Bulgarians consider the situation in this area to be unchanged or worse than it was in 2007.

The other important issue is the deteriorating media freedom in the country in recent years. According to Freedom House's Freedom of the Press 2013 survey, Bulgaria ranks $77^{\text {th }}$ and is assessed as 'partly free' in this regard. ${ }^{16}$

During the election campaign, The Economist published an article on media freedom in Bulgaria entitled 'Gravely Damaged Media Pluralism'17 in which the authors cited the latest annual Press Freedom Index from Reporters Without Borders, according to which Bulgaria now ranks $87^{\text {th }}$, down from $35^{\text {th }}$ in 2006 . Many observers are convinced that GERB, as the governing party, skilfully took advantage of the financial troubles in the media industry, securing a level of media comfort for itself via advertisements and state agency information campaigns run on the basis of public resources or EU funds.

Given this whole picture, we can conclude that the crucial question of the 2013 elections was: Would the power concentration of GERB and Borisov be broken or would GERB continue to govern the country in its populist authoritarian way? Only from this viewpoint can we understand the specifics of these elections.

15 Transparency International's Corruption Perceptions Index available at: .

16 Freedom of the Press Global Press Freedom Rankings available at: http://www.freedomhouse.org/sites/default/files/Global\%20and\%20regional\%20tables.pdf.

17 'Media Freedom in Bulgaria. Gravely Damaged Media Pluralism' The Economist 24 April 2013 . 
Table 3 - Dimensions of Bulgarian democracy, 1997-2012

\begin{tabular}{|l|c|c|c|c|c|c|c|c|c|c|}
\hline & $\mathbf{1 9 9 7}$ & $\mathbf{2 0 0 1}$ & $\mathbf{2 0 0 4}$ & $\mathbf{2 0 0 5}$ & $\mathbf{2 0 0 6}$ & $\mathbf{2 0 0 8}$ & $\mathbf{2 0 0 9}$ & $\mathbf{2 0 1 0}$ & $\mathbf{2 0 1 1}$ & $\mathbf{2 0 1 2}$ \\
\hline $\begin{array}{l}\text { Electoral } \\
\text { process }\end{array}$ & 3.25 & 2.00 & 1.75 & 1.75 & 1.75 & 1.75 & 1.75 & 1.75 & 1.75 & 2.00 \\
\hline Civil society & 4.00 & 3.50 & 3.00 & 2.75 & 2.75 & 2.50 & 2.50 & 2.50 & 2.50 & 2.50 \\
\hline $\begin{array}{l}\text { Independent } \\
\text { media }\end{array}$ & 3.75 & 3.25 & 3.50 & 3.50 & 3.25 & 3.50 & 3.75 & 3.75 & 3.75 & 3.75 \\
\hline Government & 4.25 & 3.50 & 3.75 & $\mathrm{n} / \mathrm{a}$ & $\mathrm{n} / \mathrm{a}$ & $\mathrm{n} / \mathrm{a}$ & $\mathrm{n} / \mathrm{a}$ & $\mathrm{n} / \mathrm{a}$ & $\mathrm{n} / \mathrm{a}$ & $\mathrm{n} / \mathrm{a}$ \\
\hline $\begin{array}{l}\text { National } \\
\text { democratic } \\
\text { governance }\end{array}$ & $\mathrm{n} / \mathrm{a}$ & $\mathrm{n} / \mathrm{a}$ & $\mathrm{n} / \mathrm{a}$ & 3.50 & 3.00 & 3.00 & 3.25 & 3.25 & 3.50 & 3.50 \\
\hline $\begin{array}{l}\text { Local } \\
\text { democratic } \\
\text { governance }\end{array}$ & $\mathrm{n} / \mathrm{a}$ & $\mathrm{n} / \mathrm{a}$ & $\mathrm{n} / \mathrm{a}$ & 3.50 & 3.00 & 3.00 & 3.00 & 3.00 & 3.00 & 3.00 \\
\hline $\begin{array}{l}\text { Judicial } \\
\text { framework } \\
\text { and indepen- } \\
\text { dence }\end{array}$ & 4.25 & 3.50 & 3.25 & 3.25 & 3.00 & 2.75 & 3.00 & 3.00 & 3.00 & 3.25 \\
\hline $\begin{array}{l}\text { Corruption } \\
\text { Democracy } \\
\text { score }\end{array}$ & 3.90 & 3.42 & 3.25 & 3.18 & 2.93 & 2.86 & 3.04 & 3.04 & 3.07 & 3.14 \\
\hline
\end{tabular}

Source: Compiled by author using data from Freedom House Nations in Transit http://www.freedomhouse.org/report/nations-transit/2012/bulgaria

\section{The election results and their consequences}

The first unexpected aspect of the election was the low turnout. At just $51.33 \%$, it stood significantly lower than in 2009 (62\%) and demonstrates the lowest share in all the elections thus far.

For many, this was rather surprising since increased levels of participation were expected as a result of the mass protests. Obviously, that did not happen and demonstration activity has not been transposed into electoral activity. On the other hand, one should not draw any quick conclusions in this regard. It should not be forgotten that the turnout in 2009 was unusually high as a result of the specifics of the campaign itself that year. Going back to 2005, which provides a more suitable comparison, the difference in the absolute numbers of votes is only one hundred thousand. In addition, the percentage is largely incorrect because the electoral register lists a large number of people that no longer live in Bulgaria and who have partially lost contact with it. It can be assumed that the actual number of voters is hardly more than six million, i.e. the actual turnout seems to be around $60 \%$ which is normal in the post-communist world. 
Table 4 - Parliamentary elections in Bulgaria, 1990-2013: voter turnout

\begin{tabular}{|l|c|c|}
\hline Election year & Number of votes & \% turnout \\
\hline 1990 & 6333334 & 90.60 \\
\hline 1991 & 5694842 & 83.87 \\
\hline 1994 & 5264448 & 75.23 \\
\hline 1997 & 4291257 & 58.86 \\
\hline 2001 & 4608135 & 66.62 \\
\hline 2005 & 3747822 & 55.76 \\
\hline 2009 & 4323581 & 62.00 \\
\hline 2013 & 3632174 & 51.33 \\
\hline
\end{tabular}

Source: Compiled by the author using data from: Central Election Commission http://www.cik.bg/(home page)

More worrying is the considerable degree of voter fragmentation. For the first time since 1991, a significant share of the vote went to parties that have remained outside parliament, not having managed to reach the $4 \%$ threshold for representation. This was the case for almost one-quarter of the vote. A total of nine parties gained between one and four per cent. Two of these were very close to the limit - NFSB (3.70\%); and DBG $(3.25 \%)$. Such a situation certainly creates problems for the legitimacy of the parliament and poses a danger to political stability in the country.

Only four parties exceeded the four per cent threshold and will therefore be represented in the next parliament. In comparison, there were seven in 2005 and six groups in 2009.

Despite the protests and the great dissatisfaction with the government, GERB was able to confirm its position as the strongest political party. Obviously, there has been sufficient citizens prepared to vote for the status quo or who are still influenced by Borisov's charisma. However, GERB suffered a significant loss of votes, receiving one-third (600 000) fewer votes than in 2009 and, with 97 mandates, twenty fewer seats in parliament. It should also not be forgotten that, in these elections, GERB has taken full advantage of its position as the governing party. Nevertheless, this 'victory' turned out to be nothing other than a Pyrrhic one, since GERB is not able to govern alone, on the basis of 97 out of $240 \mathrm{MPs}$, while no other parliamentary party is willing to support it in parliament. The Bulgarian voters put no confidence in parties that were regarded as future partners of GERB.

The most important result of the election was that GERB has had to go into opposition. It is questionable whether this populist party will be able to maintain its cohesion in opposition. GERB has, up to now, only functioned as a party in power and it is likely that opposition status, as well as the possible actions from the prosecutor, will weaken it. 
The Bulgarian Socialist Party (BSP) of former opposition leader and PES President, Sergei Stanishev, was able to attract nearly 200000 new votes, doubling its share of seats in the National Assembly (84 seats in 2013 compared to forty in 2009). The socialists were the only one of the parliamentary parties which succeeded in increasing their number of votes and seats in comparison with 2009. In addition, they achieved their best election result since 1994. In this election, BSP was able to reduce the gap to GERB from one million votes in 2009 to only 130000 in 2013. BSP had better results even in constituencies where some GERB politicians led the lists. The socialists missed their goal of being the leading party, but BSP has become the driving force behind a new majority in the next parliament, with 84 seats and in the context of a total isolation of GERB.

The Movement for Rights and Freedoms (DPS) has, in spite of the delicate situation after the attempted assault on its long-time chair, Ahmed Dogan, and his subsequent departure from the political scene, managed to remain the third force in parliament. The party received 200000 fewer votes than in 2009 , but it was able to retain almost the same number of seats (36 in 2013 compared to 37 in 2009). Incidentally, the DPS's 2009 election result was extremely high and, on the basis of its current level of around 400000 votes $(11.31 \%)$, it has returned to its previous results. The experiment with a new party that was intended to make DPS compete for the votes of the Turkish population failed since this new party (in coalition with the remnants of the Tsarist party NDSV) received only $1.63 \%$ of the vote.

The fourth party in the new legislature is the nationalist Ataka. It was in an extremely poor condition at the beginning of the year and no-one believed it would enter parliament. However, with a $7.3 \%$ share of the vote, Ataka seems to have been the only party that has profited from the protests. Ataka has lost about 140000 votes, but the number of its mandates increased from 21 to 23 . It will be the smallest group in parliament, but it will play a key role in this constellation of parliamentary parties.

The 2013 parliamentary election was marked by a series of 'mini surprises'.

One of these was the disappointing result for the Movement of Citizens of Bulgaria (DBG) and the failure of this new party, founded by former EU Commissioner Meglena Kuneva, to enter parliament. In the months before the protests, DBG was predicted a result of at least $10 \%$ of the vote. The dramatic reversal of the situation in Bulgaria has certainly hurt it and, with $3.25 \%$ of the vote, it has remained outside the National Assembly.

These elections also marked the end of the so-called 'traditional right' as a parliamentary party. Neither the Democrats for a Strong Bulgaria (DSB) of former Prime Minister (1997-2001) Ivan Kostov nor the coalition around the Union of Democratic Forces (SDS) was able to surpass the four per cent threshold. So, this once-mighty party, which won a majority in parliament twice in the 1990s, today - having split into small groups - has reached the periphery of Bulgarian political life. This unfortunate development is due to the inability of the right to adapt to the present and to find its own political profile after the cleavage of communism - anti-communism being significantly weakened. A new generation of politicians with new programme views are needed to maintain the chances of 'normal' centre-right parties vis-à-vis the 'centreright populist' parties which are infected with authoritarianism. 
The small but loud populist party Order, Law and Justice (RZS), which scraped into the previous legislature and was supposed to be a GERB supporter in the new parliament, received only $1.67 \%$ of the vote (fewer than 60000 ). With its shrill and demagogic behaviour and open support for Borisov, it is unlikely that it will return to big politics.

A characteristic feature of this election were the good results of parties which can be defined (with differing intensity and shades) as nationalist. Along with the impressive result of Ataka, a party established around the cable TV channel SKAT and called the National Front for the Salvation of Bulgaria (NFSB) won $3.70 \%$ of the votes. In summary, including the votes of the traditional VMRO-BND party (almost $2 \%$ ), nationalists received in total about $13 \%$ of the vote.

Finally, the parties which identified themselves with the winter protesters were not able to impress with their election results (taking less than $1 \%$ of the vote) because of their heterogeneity and the lack of a common ideological and political basis.

Table 5 - Parliamentary elections in Bulgaria: 2013 results compared to 2009

\begin{tabular}{|c|c|c|c|c|c|c|c|c|}
\hline \multirow{3}{*}{$\begin{array}{l}\text { Party / } \\
\text { Coalition }\end{array}$} & \multicolumn{4}{|c|}{2013} & \multicolumn{4}{|c|}{2009} \\
\hline & \multicolumn{2}{|c|}{ Votes } & \multicolumn{2}{|c|}{ Mandates } & \multicolumn{2}{|c|}{ Votes } & \multicolumn{2}{|c|}{ Mandates } \\
\hline & No. & $\%$ & No. & $\%$ & No. & $\%$ & No. & $\%$ \\
\hline GERB & 1081605 & 30.54 & 97 & 40.42 & 1678641 & 39.72 & 117 & 48.75 \\
\hline BSP & 942541 & 26.61 & 84 & 35.00 & 748147 & 17.70 & 40 & 16.67 \\
\hline DPS & 400466 & 11.31 & 36 & 15.00 & 610521 & 14.45 & 37 & 15.42 \\
\hline Ataka & 258481 & 7.30 & 23 & 9.58 & 395733 & 9.36 & 21 & 8.75 \\
\hline RZS & 59.145 & 1.67 & - & - & 174582 & 4.13 & 10 & 4.16 \\
\hline $\begin{array}{l}\text { Blue } \\
\text { Coalition }\end{array}$ & -- & -- & -- & -- & 285662 & 6.76 & 15 & 6.25 \\
\hline DSB-BDF & 103638 & 2.93 & - & - & - & - & - & - \\
\hline SDS & 48681 & 1.37 & - & - & - & - & - & - \\
\hline NFSB & 131169 & 3.70 & - & - & - & - & - & - \\
\hline DBG & 115190 & 3.25 & - & - & - & - & - & - \\
\hline
\end{tabular}

Source: Compiled by author using data selected from: Central Election Commission, http://results.cik.bg/ pi2013/rezultati/index.html

The crucial point of the election was, as mentioned above, the removal of GERB from power with the prospect of restoring democratic conditions in Bulgarian politics and rethinking the extreme character of austerity policies during Borisov's government. However, this will not be an easy task as far as the alternative forces also do not have a clear majority in parliament. The allocation of the mandates - 120 seats for BSP and DPS; 97 for GERB; and 23 for Ataka - shows that the two-party coalition has a majority 
against GERB in terms of the parliamentary vote, but can not form an independent quorum of 121 deputies so that a parliamentary sitting can be opened. If GERB MPs do not register (and they are continuously failing to do so), BSP and DPS need to rely on at least one Ataka-registered MP.

For the time being, the worst option for Bulgaria under these conditions - new early elections - has been avoided, regardless of the pressure of GERB which sees a new election as its only chance to govern. The country can hardly afford this in that none of the problems that provoked the protests has been resolved and that a new government is urgently needed to address these issues.

As far as a coalition between BSP and GERB is, despite being arithmetically possible, politically unthinkable, and since a coalition between the three parties other than GERB (BSP plus DPS and Ataka) is impossible because of the enmity between DPS and Ataka, and as a result of the nature of Ataka in general, the only option that remained was a 'non-partisan government' with an expert character and not based on any formal coalition agreement. In this direction lay the proposal of the socialists during the election campaign heralding the non-party ex-finance minister, Plamen Oresharski, as a candidate for future prime minister. The idea found sufficient support in DPS and was tolerated by Ataka MPs; representing enough for a parliamentary majority.

It is clear that one of the most delicate aspects of parliamentary support for this kind of government, in view of democratic values and democratic stability, is the role of Ataka. Ataka arose as a nationalist party, but it also a party of protest and has established itself as such. This is the first time that it has received a key role in parliamentary life. On the one hand, Ataka has no interest in elections because it could lose this important role and gain nationalist competitors in the next parliament. On the other hand, it is being strongly attacked by GERB and NFSB as an alleged collaborator of the archenemy DPS and as part of a coalition with the 'Turkish party', which could bring about problems with its social base. One can expect that Ataka will retain its character but, at critical moments, will prevent a parliamentary crisis and a possible new election. This will obviously be the price for the ending of Borisov's rule and the avoidance of early elections.

At the end of the day, on 29 May 2013, based on 120 votes from BSP and DPS (and one vote from Ataka for a quorum), the National Assembly elected Oresharski as Prime Minister and endorsed his cabinet.

The biography of the new Prime Minister points to pragmatism and expertise. He comes from academic circles and previously in his political career served both as deputy finance minister in an SDS government (1997-2001) and as finance minister in the BSP-dominated government (2005-2009). Despite being elected to parliament on the BSP list, he is not a member of the party. His government programme does not coincide with the electoral manifestos of the parties supporting his cabinet. Its core is the restoration of political and democratic stability, boosting the stagnant economy and the taking of urgent social measures in respect of the poorest parts of the population.

This government was born out of necessity and will have to confront the at least initial distrust of the public as well as the permanent obstructionism of GERB. The behaviour of GERB in the new parliament shows that it will rely on boycott tactics and will try continuously to destabilise parliamentary and political life. Together with its 
blocking of normal parliamentary activity, the provocation and incitement of street passions are possible, as is the ethnicisation of political conflicts.

With the formation of the government, the political crisis in Bulgaria seems to have reached an end for the time being, but the key question in the current unusual situation remains open: Is Bulgaria's fragile democracy able to overcome the 'Borisov phenomenon', with its tendencies of authoritarian populism, and thus further develop into a consolidated democracy, with a vital and more socially-oriented economy? 